\title{
Lack of association between polymorphisms in the UBASH3A gene and autoimmune thyroid disease: a case control study
}

\author{
Falta de associação entre polimorfismos do gene UBASH3A \\ e doença tiroidiana autoimune: estudo caso controle
}

TianTian Cai', Xuan Wang', Fatuma-Said Muhali', RongHua Song', XiaoHong Shi ${ }^{2}$, WenJuan Jiang ${ }^{2}$, Ling $\mathrm{XiaO}^{2}$, DanFeng $\mathrm{Li}^{2}$, JinAn Zhang ${ }^{2}$

${ }^{1}$ Clinical Research Center, The First Affiliated Hospital of Medical School, Xi'an Jiaotong University, Xi'an, China ${ }^{2}$ Department of Endocrinology, Jinshan Hospital of Fudan University, Shanghai, China

\author{
Correspondence to: \\ JinAn Zhang \\ Department of Endocrinology, \\ Jinshan Hospital of Fudan \\ University, 1508 \\ 201508 - Longhang Road, Shanghai, \\ China \\ zhangjinan@hotmail.com \\ Received on Jan/4/2014 \\ Accepted on Apr/10/2014 \\ DOI: 10.1590/0004-2730000003209
}

\begin{abstract}
Objective: The aim of this study was to investigate UBASH3A gene variation association with autoimmune thyroid disease and clinical features in a Chinese Han population. Subjects and methods: A total of 667 AITD patients (417 GD and $250 \mathrm{HT}$ ) and 301 healthy controls were genotyped for two single nucleotide polymorphisms (SNPs) rs11203203, rs3788013 of UBASH3A gene, utilizing the Matrix Assisted Laser Desorption lonization-Time of Flight Mass Spectrometer (MALDI-TOF-MS) Platform. Results: Between the control group and AITD, GD and HT group, no statistically significant difference was observed in the genotypic and allelic frequencies of the two SNPs. There was no significant difference in allelic frequencies of the two SNPs between GD with and without ophthalmopathy. There was no significant difference in haplotype distributions between the control group and AITD, GD or HT group. Conclusion: Rs 11203203 and rs3788013 in UBASH3A gene may not be associated with AITD patients in Chinese Han population. Arq Bras Endocrinol Metab. 2014;58(6):640-5
\end{abstract}

\section{Keywords}

Autoimmune thyroid disease (AITD); Graves' disease (GD); Hashimoto's thyroiditis (HT); ubiquitin associated and SH3 domain containing A (UBASH3A); single nucleotide polymorphism (SNP)

\section{RESUMO}

Objetivo: 0 objetivo deste estudo foi investigar a variação no gene UBASH3A com a doença tiroidiana autoimune e características clínicas na população chinesa Han. Sujeitos e métodos: Um total de 667 pacientes com DTAI (417 com DG e 250 com TH) e 301 controles saudáveis foi genotipado para dois polimorfismos de nucleotídeo simples (SNPs) rs11203203, rs3788013 do gene UBASH3A, usando-se a plataforma MALDI-TOF-MS (Ionização/Dessorção de Matriz Assistida por Laser - Tempo de Voo/Espectrômetro de Massa). Resultados: Não foram observadas diferenças significativas entre as frequências genotípicas e alélicas dos dois SNPs nos grupos controle e DTAl, DG eTH. Não houve diferenças significativas entre as frequências alélicas dos dois SNPs em pacientes com DG com ou sem olftalmopatia. Não houve diferenças significativas nas distribuições de haplótipos no grupo controle e nos grupos DTAl, DG eTH. Conclusão: Os SNPs rs 11203203 e rs3788013 do gene UBASH3A podem não estar associados a pacientes com DTAI na população chinesa Han. Arq Bras Endocrinol Metab. 2014;58(6):640-5

\section{Descritores}

Doença tireoidiana autoimune (DTAl); doença de Graves (DG); tireoidite de Hashimoto (TH); ubiquitina associada e domínio SH3 contendo A (UBASH3A); polimorfismos de nucleotídeo simples (SNP) 


\section{INTRODUCTION}

A utoimmune thyroid disease (AITD) is one group of organ-specific autoimmune disease encompassing Graves' disease (GD) and Hashimoto's thyroiditis (HT), which affects between $2 \%-4 \%$ of women and up to $1 \%$ of men (1). Hitherto, the etiology of AITD remains largely unknown, but environmental factors and genetic predisposition are believed to be involved in it (2). AITD usually occurs after a series of genetic and environmental factors. It has long been established that major genetic predisposition to this disease is mainly contributed by variation of several classic immune-related genes, particularly genes of human leukocyte antigen $(H L A)(3,4)$, cytotoxic T-lymphocyte-associated antigen-4 (CTLA-4) $(5,6), C D 40(7)$, and protein tyrosine phosphatase-22 (PTPN22) $(8,9)$. In addition, other thyroid-specific genes are also reported to be associated with AITD, such as the genes of thyroid stimulating hormone receptor (TSHR) $(10,11)$ and thyroglobulin $(T g)(12,13)$. Currently, genome-wide association (GWA) studies have had a dramatic impact on susceptibility locus discovery, leading to more novel regions of the genome emerging as AITD susceptibility loci.

The gene UBASH3A encodes one of two family members which belong to the T-cell ubiquitin ligand (TULA) family. UBASH3A is a potent regulator of cellular functions and is expressed predominantly in T-cells, having a suppressing effect on TCR signaling and activation (14). Lack of TULA proteins resulted in hyper-reactivity of T cells (15). Recently, more studies have reported that it is the newly uncovered gene associated with various autoimmune diseases (16-19). In present study, we performed a case-control study of AITD in a Chinese Han population, attempting to find the potential association of rs11203203 and rs3788013 in the UBASH3A gene with GD and HT.

\section{MATERIALS AND METHODS}

\section{Patients and controls}

Our study investigated 667 AITD patients, including $417 \mathrm{GD}$ patients and $250 \mathrm{HT}$ patients. All patients were diagnosed according to both clinical and biochemical evidences, and the one with other autoimmune and genetic diseases was ruled out. The diagnostic criteria for GD were mainly determined by 1) clinical manifestation and laboratory biochemical proof of hyperthyroidism; 2) the presence of diffuse goiter; 3 ) the presence of thyroid-associated ophthalmopathy (TAO); 4) the presence of pretibial myxedema; 5 ) the positive circulating TRAb or TPOAb. HT was defined on the basis of enlarged thyroid, and the high level of either TPOAb or $\operatorname{TgAb}$, with or without clinical and biochemical hypothyroidism. For the suspicious cases of HT, diagnoses were confirmed by fine needle aspiration biopsies (FNAC). Presence of AITD family history was defined as the subjects' first-degree relatives including parents, children and siblings or second-degree relatives such as grandparents, uncles and aunts who had AITD occurrence. Another 301 healthy individuals were enrolled as a control group, and the one with thyroid diseases or other autoimmune diseases was excluded from this category. Besides, negative TPOAb necessitates for control individual screening. All the subjects were unrelated Chinese Han people and enrolled with informed consent from the First Affiliated Hospital of Xi'an Jiaotong University. The research project was approved by the Ethics Committee of the hospital.

\section{Genomic DNA extraction and genotyping}

$2 \mathrm{ml}$ peripheral venous blood from the subjects was obtained by venipuncture and collected in an EDTA tube. Genomic DNA was extracted by standard procedure using RelaxGene Blood DNA System (TIANGEN BIOTECH, BEIJING, China). SNP genotype information was downloaded from the HapMap $\mathrm{CHB}$ population (corresponding to samples with Beijing of China ancestry). Genotyping rs1 1203203 and rs3788013 was performed using Matrix Assisted Laser Desorption Ionization-Time of Flight Mass Spectrometer (MALDI-TOF-MS) Platform from Sequenom (San Diego, CA, USA) in collaboration with Shanghai Benegene Biotechnologies CO. LTD (Shanghai, China).

\section{Statistical analysis}

The clinical data were expressed as $\mathrm{M} \pm \mathrm{SD}$. The difference of genotypic and allelic frequencies distributions was analyzed by $\chi^{2}$ test or Fisher's exact test. Hardy-Weinberg equilibrium (HWE) test, haplotype frequency calculation and linkage disequilibrium (LD) test were performed using HaploView 4.2. All statistical analyses were performed using the software SPSS version 18.0 and a $P$ value less than 0.05 was considered statistically significant. The odds ratio (OR) was calculated from genotypic and allelic frequencies with 95\% confidence interval (CI). 


\section{RESULTS}

\section{Clinical data analysis}

Our study investigated 667 AITD patients, including 417 GD patients $(29.74 \%$ male and $70.26 \%$ female, aged $5-73$, mean age $34.48 \pm 13.95)$ and $250 \mathrm{HT}$ patients ( $15.60 \%$ male and $84.40 \%$ female, aged $4-77$, mean age $31.9 \pm 13.10)$. In GD patients, the average onset of age is $32.31 \pm 14.07,98$ individuals had ophthalmopathy and 72 had family history $(23.5 \%$ and $17.27 \%$, respectively). In HT patients, the average onset of age was $30.29 \pm 13.05,6$ individuals had ophthalmopathy and 54 had family history $(2.40 \%$ and $21.60 \%$, respectively).

\section{Allele and genotyping results}

Both of the two SNPs in control group were in HWE $(\mathrm{P}>0.05)$. The distributions of allelic, genotypic frequencies and case-control association analysis are shown in table 1 and table 2. For rsl1203203, the frequency of minor allele A was higher in AITD and GD group $(5.93 \%$ and $6.25 \%$, respectively) than that in control group $(5.72 \%)$, while the frequency in HT group $(5.40 \%)$ was somehow lower than that of control group. Likewise, for rs3788013, the frequency of minor allele A was also higher in AITD and GD group $(33.88 \%$ and $34.53 \%$, respectively) than that of control group $(33.00 \%)$, while frequency in HT $(32.80 \%)$ was lower than that in control group. However, the differences of these allele frequencies between cases and controls were not found statistically significant. The frequency of variant genotype AA of rs 11203203 was higher in all the patients $(0.60 \%$ in AITD, $0.48 \%$ in GD, and $0.80 \%$ in $\mathrm{HT}$ ) than that in control group $(0.34 \%)$. However, when wild-type homozygote GG was used as the reference, no statistically significant risk was observed for AITD, GD and HT of variant genotype AA, AG and the combination (AG+AA). The frequency of variant genotype AA of rs3788013 was only higher in AITD and GD group (11.24\% in AITD, $12.47 \%$ in GD) than that in control group (11.00\%). When wild-type homozygote CC was used as the reference, no statistically significant risk was observed for AITD, GD and HT of variant genotype AA, AC and the combination $(\mathrm{AC}+\mathrm{AA})$.

Given that T-cell induced immunity plays an important role in the pathogenesis of GO (20), we further investigated the two SNPs for association with the sub- set of GD patients that had ophthalmopathy. Table 3 shows allele distributions and case-control association analysis in ophthalmopathy/non-ophthalmopathy patients and controls. For rs11203203, the frequencies of allele A were higher in GD patients with and without ophthalmopathy $(7.14 \%$ and $5.97 \%$, respectively) than that in control group (5.72\%); furthermore, the frequency of allele A was higher in GO than that in GD without ophthalmopathy. For rs3788013, the frequencies of allele A were higher in GD patients with and without ophthalmopathy $(33.67 \%$ and $34.80 \%$, respectively) than that in control group $(33.00 \%)$; however, the frequency of allele A was a little lower in GO than that in GD without ophthalmopathy. None of these differences reached statistical significance.

\section{Haplotype analysis}

According to the Hapmap CHB data, $D^{\prime}$ and $r^{2}$ for LD test of the two SNPs were 1.0 and 0.121 . Although they were not in one block, we performed haplotype analysis. Four possible haplotypes were detected from the SNPs. As shown in table 4, the frequencies of three halotypes were greater than 0.05 , of which GC and GA were the most frequent ones, both in cases and

Table 1. Allele and genotype distributions in AITD patients and controls

\begin{tabular}{|c|c|c|c|c|}
\hline SNP & $\begin{array}{c}\text { Control } \\
\text { (\%) }\end{array}$ & AITD (\%) & $\begin{array}{c}\text { AITD } \\
\text { vs. Con } \\
\text { P value }\end{array}$ & $\begin{array}{c}\text { OR } \\
(95 \% \mathrm{Cl})\end{array}$ \\
\hline \multicolumn{5}{|c|}{ rs 11203203} \\
\hline \multicolumn{5}{|l|}{ Allele } \\
\hline A & 34 (5.72) & 79 (5.93) & 0.858 & $1.04(0.69-1.57)$ \\
\hline G & 560 (94.28) & $1253(94.07)$ & & \\
\hline \multicolumn{5}{|c|}{ Genotype } \\
\hline GG & 264 (88.89) & 591 (88.74) & & 1.00 \\
\hline$A G$ & $32(10.77)$ & $71(10.66)$ & 0.968 & $0.99(0.64-1.54)$ \\
\hline AA & $1(0.34)$ & $4(0.60)$ & 0.968 & $1.79(0.20-16.06)$ \\
\hline$A G+A A$ & 33 (11.11) & 75 (11.26) & 0.946 & $1.02(0.66-1.57)$ \\
\hline \multicolumn{5}{|c|}{ rs 3788013} \\
\hline \multicolumn{5}{|l|}{ Allele } \\
\hline A & $198(33.0)$ & $452(33.88)$ & 0.704 & $1.04(0.85-1.28)$ \\
\hline C & $402(67.0)$ & 882 (66.12) & & \\
\hline \multicolumn{5}{|c|}{ Genotype } \\
\hline $\mathrm{CC}$ & $135(45.00)$ & $290(43.48)$ & & 1.00 \\
\hline$A C$ & $132(44.00)$ & $302(45.28)$ & 0.669 & $1.07(0.80-1.42)$ \\
\hline AA & $33(11.00)$ & 75 (11.24) & 0.809 & $1.06(0.67-1.67)$ \\
\hline $\mathrm{AC}+\mathrm{AA}$ & $165(55.00)$ & 377 (56.52) & 0.659 & $1.06(0.81-1.40)$ \\
\hline
\end{tabular}


controls. All the differences of haplotype distributions were not statistically significant. When haplotype GC was used as the reference, the combination of other ha- lotypes (non-GC) showed no significant risk for all the patients $(\mathrm{p}=0.672,0 \mathrm{R}=0.96$ for $\mathrm{AITD} ; \mathrm{p}=0.485,0 \mathrm{R}$ $=1.08$ for $\mathrm{GD} ; \mathrm{p}=0.963,0 \mathrm{R}=1.00$ for $\mathrm{HT}$ ).

Table 2. Allele and genotype distributions in GD, HT patients and controls

\begin{tabular}{|c|c|c|c|c|c|c|c|}
\hline SNP & Control (\%) & GD (\%) & HT (\%) & $\begin{array}{l}\text { GD vs. Con } \\
\text { P value }\end{array}$ & $\begin{array}{c}\text { OR } \\
(95 \% \mathrm{Cl})\end{array}$ & $\begin{array}{c}\text { HT vs. Con } \\
\text { P value }\end{array}$ & $\begin{array}{c}\text { OR } \\
(95 \% \mathrm{Cl})\end{array}$ \\
\hline \multicolumn{8}{|c|}{ rs 11203203} \\
\hline \multicolumn{8}{|l|}{ Allele } \\
\hline$A$ & $34(5.72)$ & $52(6.25)$ & $27(5.40)$ & 0.681 & $1.10(0.70-1.72)$ & 0.816 & $0.94(0.56-1.58)$ \\
\hline G & $560(94.28)$ & 780 (93.75) & $473(94.60)$ & & & & \\
\hline \multicolumn{8}{|c|}{ Genotype } \\
\hline GG & 264 (88.89) & 366 (87.98) & $225(90.00)$ & & 1.00 & & 1.00 \\
\hline$A G$ & $32(10.77)$ & $48(11.54)$ & $23(9.20)$ & 0.745 & $1.08(0.67-1.74)$ & 0.554 & $0.84(0.48-1.48)$ \\
\hline$A A$ & $1(0.34)$ & $2(0.48)$ & $2(0.80)$ & 1.000 & $1.44(0.13-15.99)$ & 0.893 & $2.35(0.21-26.05)$ \\
\hline$A G+A A$ & $33(11.11)$ & $50(12.02) 5$ & $25(10.00)$ & 0.709 & $1.09(0.69-1.74)$ & 0.674 & $0.89(0.51-1.54)$ \\
\hline \multicolumn{8}{|c|}{ rs 3788013} \\
\hline \multicolumn{8}{|l|}{ Allele } \\
\hline$A$ & $198(33.0)$ & 288 (34.53) & $164(32.80)$ & 0.545 & 1.07 (0.86-1.34) & 0.944 & $0.99(0.77-1.28)$ \\
\hline C & $402(67.0)$ & $546(65.47)$ & $336(67.20)$ & & & & \\
\hline \multicolumn{8}{|c|}{ Genotype } \\
\hline $\mathrm{CC}$ & $135(45.00)$ & $181(43.41)$ & 109 (43.60) & & 1.00 & & 1.00 \\
\hline$A C$ & $132(44.00)$ & $184(44.12)$ & $118(47.20)$ & 0.809 & $1.04(0.76-1.43)$ & 0.573 & $1.11(0.78-1.58)$ \\
\hline $\mathrm{AA}$ & $33(11.00)$ & $52(12.47)$ & $23(9.20)$ & 0.518 & $1.18(0.72-1.92)$ & 0.624 & $0.86(0.48-1.56)$ \\
\hline $\mathrm{AC}+\mathrm{AA}$ & $165(55.00)$ & $236(56.59)$ & $141(56.40)$ & 0.671 & $1.07(0.79-1.44)$ & 0.742 & $1.06(0.76-1.48)$ \\
\hline
\end{tabular}

Table 3. Allele distributions in ophthalmopathy, non-ophthalmopathy patients among GD patients and controls

\begin{tabular}{|c|c|c|c|c|c|c|c|c|c|}
\hline \multirow{2}{*}{ SNP } & \multirow{2}{*}{ Control (\%) } & \multicolumn{2}{|c|}{ GD patients } & \multirow{2}{*}{$\begin{array}{c}\text { non-GO vs. } \\
\text { Con } \\
\text { P value }\end{array}$} & \multirow{2}{*}{$\begin{array}{c}\text { OR } \\
(95 \% \mathrm{Cl})\end{array}$} & \multirow{2}{*}{$\begin{array}{c}\text { GO } \\
\text { vs. Con } \\
\text { P value }\end{array}$} & \multirow{2}{*}{$\begin{array}{c}\text { OR } \\
\text { (95\%Cl) }\end{array}$} & \multirow{2}{*}{$\begin{array}{c}\text { GO } \\
\text { vs. non-GO } \\
\text { P value } \\
\end{array}$} & \multirow{2}{*}{$\begin{array}{c}\text { OR } \\
(95 \% \text { Cl) }\end{array}$} \\
\hline & & non-GO (\%) & GO (\%) & & & & & & \\
\hline \multicolumn{10}{|c|}{ rs 11203203} \\
\hline A & 34 (5.72) & 38 (5.97) & $14(7.14)$ & 0.851 & $\begin{array}{c}1.05 \\
(0.65-1.69)\end{array}$ & 0.471 & $\begin{array}{c}1.27 \\
(0.67-2.41)\end{array}$ & 0.555 & $\begin{array}{c}1.21 \\
(0.64-2.28\end{array}$ \\
\hline G & $560(94.28)$ & $598(94.03)$ & $182(92.86)$ & & & & & & \\
\hline \multicolumn{10}{|c|}{ rs 3788013} \\
\hline A & $198(33.00)$ & $222(34.80)$ & 66 (33.67) & 0.505 & $\begin{array}{c}1.08 \\
(0.86-1.37)\end{array}$ & 0.862 & $\begin{array}{c}1.03 \\
(0.73-1.45)\end{array}$ & 0.772 & $\begin{array}{c}0.95 \\
(0.68-1.33\end{array}$ \\
\hline C & $402(67.00)$ & $416(65.20)$ & 130 (66.33) & & & & & & \\
\hline
\end{tabular}

Table 4. Haplotype analyses in AITD patients and controls

\begin{tabular}{|c|c|c|c|c|c|c|c|c|c|c|}
\hline Haplotype & $\begin{array}{c}\text { Control } \\
\text { (Frequency) }\end{array}$ & $\begin{array}{c}\text { AITD } \\
\text { (Frequency) }\end{array}$ & $\begin{array}{c}\text { GD } \\
\text { (Frequency) }\end{array}$ & $\begin{array}{c}\text { HT } \\
\text { (Frequency) }\end{array}$ & $\begin{array}{l}\text { AITD vs. } \\
\text { Con } \\
\text { P value }\end{array}$ & $\begin{array}{c}\text { OR } \\
(95 \% \text { Cl) }\end{array}$ & $\begin{array}{c}\text { GD } \\
\text { vs. Con } \\
\text { P value }\end{array}$ & $\begin{array}{c}\text { OR } \\
(95 \% \mathrm{Cl})\end{array}$ & $\begin{array}{c}\text { HT } \\
\text { vs. Con } \\
\text { P value }\end{array}$ & $\begin{array}{c}\text { OR } \\
(95 \% \text { Cl) }\end{array}$ \\
\hline $\mathrm{GC}$ & 402 (0.670) & $880(0.664)$ & 544 (0.653) & 335 (0.669) & 0.672 & 1.00 & 0.485 & 1.00 & 0.963 & 1.00 \\
\hline GA & 163 (0.272) & 375 (0.278) & $237(0.284)$ & $138(0.277)$ & 0.661 & & 0.602 & & 0.888 & \\
\hline$A C$ & $0(0.000)$ & $1(0.001)$ & $2(0.002)$ & $2(0.003)$ & 1.000 & & 0.513 & & 0.207 & \\
\hline $\mathrm{AA}$ & $35(0.058)$ & $77(0.057)$ & $51(0.061)$ & $26(0.051)$ & 0.960 & & 0.825 & & 0.642 & \\
\hline Non-GC & $198(0.330)$ & $453(0.336)$ & $290(0.347)$ & $166(0.331)$ & 0.672 & $\begin{array}{c}0.96 \\
(0.78-1.17)\end{array}$ & 0.485 & $\begin{array}{c}1.08 \\
(0.87-1.35)\end{array}$ & 0.963 & $\begin{array}{c}1.00 \\
(0.78-1.30)\end{array}$ \\
\hline
\end{tabular}




\section{DISCUSSION}

The gene UBASH3A, whose official full name is ubiquitin associated and $\mathrm{SH} 3$ domain containing $\mathrm{A}$, is located on chromosome 21 (2lq22.3), spanning 40kb and containing 15 exons. Initially, this gene was isolated and characterized by a study focused on identifying candidate genes on chromosome $21 \mathrm{lq} 22.3$ for autosomal recessive nonsyndromic deafness (DFNB10) (21). TULA/ STS-2/UBASH3A and TULA-2/STS-1/UBASH3B are both members of the $\mathrm{T}$ cell ubiquitin ligand proteins (TULA) family. Both of them are suppressors of TCR signaling and can regulate TCR signaling pathways negatively. The two proteins exhibit a unique architecture comprised of three conserved and functional domain: an N-terminal ubiquitin associated (UBA) domain that can bind mono- and poly-ubiquitin, a central Src homology 3 (SH3) domain which can participate in protein-protein interactions, and a C-terminal PGM (phosphoglycerate mutase) acting as phosphatases or phosphotransferases $(14,22)$. Unlike the other protein, TULA/STS-2/UBASH3A is only expressed within lymphocytes and has a low phosphatase activity but a unique ability of promoting T-cell apoptosis $(23,24)$. Hence, it may set its suppressing effect on $\mathrm{T}$ cell signaling and $\mathrm{T}$ cell activation by dephosphorylation of unknown substrates or by apoptosis in T cells. As we all know, the pathologic mechanisms of many autoimmune disorders, including GD and HT, are correlated with immune system abnormality. Under the background of genetic predisposition, environmental factors, such as stress, infection and trauma, may cause the functional and quantitative decrease of suppressor T cells (Ts), which interfere with inhibition of helper $\mathrm{T}$ cells $(\mathrm{Th})$ activation within thyroid tissues. Consequently, auto-antigens are presented to Th cells in a recognizable pattern, leading to a pathological immune response and ultimately the activation of $\mathrm{B}$ cells which can produce auto-antibodies targeting the thyroid itself. Inadequate mutations in auto-antigens or hyper-response to TCR stimulation could result in the disturbance of self immune tolerance. Therefore, we hypothesized that polymorphisms within the gene UBASH $3 A$ could cause changes in the expression and function of the protein. These changes could affect down-regulation of $\mathrm{T}$ cell activation and apoptosis, break down a balanced immune response, result in a hyper-reactivity of $\mathrm{T}$ cell and finally lead to the occurrence of AITD.

In this study, we investigated the association between two intronic SNPs (rs11203203 and rs3788013) of UBASH3A gene and AITD patients in a Chinese Han population. We found that the frequencies of allele A in the two SNPs were increased in both AITD and GD group. The AA genotype frequencies of the two SNPs in AITD and GD were also higher than that in control group. Furthermore, we found that the frequencies of allele A from rs11203203 were higher in GD patients with and without ophthalmopathy than that in control group; moreover, the frequency of allele A was higher in GO than that in GD without ophthalmopathy. Nevertheless, it was a pity that none of these above-mentioned differences reached statistical significance. The term haplotype refers to physical arrangement of SNP alleles along a chromosome (25). It is demonstrated that analysis based on haplotype would be more powerful and effective to detect an association than those based on individual SNPs. However, our study did not find any association between the four haplotypes and AITD, GD or HT group. To sum up, these results have suggested that the allele A of two SNPs may play no role in the pathogenesis of AITD or that its effect may be confounded by other various factors.

It has been generally accepted that a case-control study is efficient enough to detect the association between candidate genes and diseases. However, this method and design is usually limited to various elements. Inadequate sample size, gender, age, different ethnic group and low power statistical methods are common confounding factors in a case-control study (26-28). Those problems were also shown in our study. Our findings provided no significant evidence that the gene UBASH3A was associated with susceptibility to AITD in Chinese Han population. This disaccorded with the analysis of association between 2,477 cases with Graves' disease and rs3788013 of UBASH3A in white ethnic group from British cohort (29). This dichotomy could be attributed to ethnic diversity, relative small sample size and other different elements. Therefore, we are motivated to investigate more loci in this gene with a larger sample size and in different nations among Chinese people in order to capture the genetic contributions by UBASH3A in the pathogenesis of AITD.

Acknowledgement: this work was supported by grants from the National Natural Science Foundation of China (81270871, 81070627).

Disclosure: no potential conflict of interest relevant to this article was reported. 


\section{REFERENCES}

1. Vaidya B, Kendall-Taylor P, Pearce SH. The genetics of autoimmune thyroid disease. JCEM. 2002;87:5385-97.

2. TomerY, DaviesTF. Searching for the autoimmune thyroid disease susceptibility genes: from gene mapping to gene function. Endocr Rev. 2003;24:694-717.

3. Simmonds MJ, Howson JM, Heward JM, Carr-Smith J, Franklyn JA, Todd JA, et al. A novel and major association of HLA-C in Graves' disease that eclipses the classical HLA-DRB1 effect. Hum Mol Genet. 2007;16:2149-53.

4. Simmonds MJ, Howson JM, Heward JM, Cordell HJ, Foxall $H$, Carr-Smith J, et al. Regression mapping of association between the human leukocyte antigen region and Graves disease. Am J Hum Genet. 2005;76:157-63.

5. Kavvoura FK, Akamizu T, Awata T, BanY, Chistiakov DA, Frydecka I, et al. Cytotoxic T-lymphocyte associated antigen 4 gene polymorphisms and autoimmune thyroid disease: a meta-analysis. J Clin Endocrinol Metab. 2007;92:3162-70.

6. Yang J, Qin Q, Yan N, ZhuYF, Li C, Yang XJ, et al. CD40 C/T(-1) and CTLA-4 A/G(49) SNPs are associated with autoimmune thyroid diseases in the Chinese population. Endocrine. 2012;41:111-5.

7. Mukai T, HiromatsuY, Fukutani $T$, Ichimura $M$, Kaku $H$, Miyake I, et al. A C/T polymorphism in the $5^{\prime}$ untranslated region of the CD40 gene is associated with later onset of Graves' disease in Japanese. Endocr J. 2005;52:471-7.

8. Velaga MR, Wilson V, Jennings $C E$, Owen $C J$, Herington $S$, Donaldson PT, et al. The codon 620 tryptophan allele of the lymphoid tyrosine phosphatase (LYP) gene is a major determinant of Graves' disease. J Clin Endocrinol Metab. 2004;89:5862-5.

9. Heward JM, Brand OJ, Barrett JC, Carr-Smith JD, Franklyn JA, Gough SC. Association of PTPN22 haplotypes with Graves' disease. J Clin Endocrinol Metab. 2007;92:685-90.

10. Brand OJ, Barrett JC, Simmonds MJ, Newby PR, McCabe CJ, Bruce $\mathrm{CK}$, et al. Association of the thyroid stimulating hormone receptor gene (TSHR) with Graves' disease. Hum Mol Genet. 2009;18:1704-13.

11. Liu L, Wu HQ, Wang Q, Zhu YF, Zhang W, Guan LJ, et al. Association between thyroid stimulating hormone receptor gene intron polymorphisms and autoimmune thyroid disease in a Chinese Han population. Endocr J. 2012;59:717-23.

12. Tomer Y, Greenberg DA, Concepcion E, Ban Y, Davies TF. Thyroglobulin is a thyroid specific gene for the familial autoimmune thyroid diseases. J Clin Endocrinol Metab. 2002;87:404-7.

13. Ban $Y$, Tozaki T, Taniyama M, Skrabanek $L$, Nakano $Y$, Ban $Y$, et al. Multiple SNPs in intron 41 of thyroglobulin gene are associated with autoimmune thyroid disease in the Japanese Population. PLoS One. 2012;7:e37501.
14. Tsygankov AY. Multidomain STS/TULA proteins are novel cellular regulators. IUBMB Life. 2008;60:224-31.

15. Tsygankov AY.TULA-family proteins: an odd couple. Cell Mol Life Sci. 2009;66:2949-52.

16. Concannon $P$, Onengut-Gumuscu $S$, Todd JA, Smyth DJ, Pociot $F$, Bergholdt $R$, et al. A human type 1 diabetes susceptibility locus maps to chromosome 21q22.3. Diabetes. 2008;57:2858-61.

17. Grant SF, Qu HQ, Bradfield JP, Marchand L, Kim CE, Glessner JT, et al. Follow-up analysis of genome-wide association data identifies novel loci for type 1 diabetes. Diabetes. 2009;58:290-5.

18. Jin Y, Birlea SA, Fain PR, Gowan K, Riccardi SL, Holland PJ et al. Variant ofTYR and autoimmunity susceptibility loci in generalized vitiligo. N Engl J Med. 2010;362:1686-97.

19. Zhernakova A, Stahl EA, Trynka G, Raychaudhuri S, Festen EA, Franke $L$, et al. Meta-analysis of genome-wide association studies in celiac disease and rheumatoid arthritis identifies fourteen non-HLA shared Loci. PLoS Genet. 2011;7:e1002004.

20. Bahn RS. Clinical review 157: pathophysiology of Graves' ophthalmopathy: the cycle of disease. J Clin Endocrinol Metab. 2003;88:1939-46.

21. Wattenhofer M, Shibuya K, Kudoh J, Lyle R, Michaud J, Rossier $\mathrm{C}$, et al. Isolation and characterization of the UBASH3A gene on 21q22.3 encoding a potential nuclear protein with a novel combination of domains. Hum Genet. 2001;108:140-7.

22. San Luis B, Sondgeroth B, Nassar N, Carpino N. Sts-2 is a phosphatase that negatively regulates zeta-associated protein (ZAP)-70 and T cell receptor signaling pathways. J Biol Chem. 2011;286:15943-54.

23. Carpino N, Chen Y, Nassar N, Oh HW. The Sts proteins target tyrosine phosphorylated, ubiquitinated proteins within TCR signaling pathways. Mol Immunol. 2009;46:3224-31.

24. Collingwood TS, Smirnova EV, Bogush M, Carpino N, Annan RS, Tsygankov AY. T-cell ubiquitin ligand affects cell death through a functional interaction with apoptosis-inducing factor, a key factor of caspase-independent apoptosis. J Biol Chem. 2007;282:30920-8.

25. Olivier M. A haplotype map of the human genome. Physiol Genomics. 2003;13:3-9.

26. Mao R, FanY, Zuo L, Geng D, Meng F, Zhu J, et al. Association study between methylenetetrahydrofolate reductase gene polymorphisms and Graves' disease. Cell Biochem Funct. 2010;28:585-90.

27. Schaid DJ.Transmission disequilibrium, family controls, and great Expectations. Am J Hum Genet. 1998;63:935-41.

28. Collins A. Approaches to the identification of susceptibility genes. Parasite Immunol. 2009;31:225-33.

29. Plagnol V, Howson JM, Smyth DJ, Walker N, Hafler JP, Wallace C, et al. Genome-wide association analysis of autoantibody positivity in type 1 diabetes cases. PLoS Genet. 2011;7:e1002216. 